\title{
PENDAYAGUNAAN KELOMPOK DISKUSI MAHASISWA DALAM MENANGKAL PAHAM RADIKALISME DAN PAHAM TERORISME DI LINGKUNGAN PERGURUAN TINGGI
}

\author{
Humaizi $^{1}$, R. Hamdani Harahap ${ }^{2}$, Ridwan Hanafiah ${ }^{3}$, Rudi Salam Sinaga ${ }^{4}$ \\ ${ }^{123}$ Fakultas Ilmu Sosial dan Ilmu Politik Universitas Sumatera Utara \\ humaizi_fisipusu@yahoo.com \\ ${ }^{4}$ Fakultas Ilmu Sosial dan Ilmu Politik Universitas Medan Area \\ rudisalam@staff.uma.ac.id
}

\begin{abstract}
Abstrak
Kelompok terorisme secara nyata telah meletakkan perhatian mereka untuk merekrut anggota baru dari kalangan terpelajar seperti mahasiswa yang masih studi perguruan tinggi, sejumlah pelaku terorisme yang telah tertangkap menunjukan status sebagai pelajar atau mahasiswa. Kami menilai salah satu cara yang penting untuk dibudayakan dalam lingkungan perguruan tinggi ialah dengan melakukan mengkampanyekan anti paham radikal dan anti paham teoris secara rutin serta mengkampanyekan cara yang tepat untuk menangani situasi yang terarah pada pemikiran dan tindakan radikal dan terorisme. Studi ini akan melihat persepsi mahasiswa di lingkungan Fakultas Ilmu Sosial dan Ilmu Politik Universitas Sumatera Utara terhadap bahaya paham radikal dan paham terorisme serta solusi pencegahan bagi keamanan lingkungan sekitar mereka. Metode yang digunakan pada studi ini studi pustaka, dokumentasi dan focus group discussion (FGD). Hasil studi ini memperlihatkan apresiasi yang kuat dari kelompok diskusi mahasiswa terhadap maksud dan tujuan kegiatan ini.
\end{abstract}

Kata kunci: Pendayagunaan, Kelompok diskusi, Mahasiswa, Radikalisme, Terorisme

\begin{abstract}
Terrorism groups have obviously put their attention to recruiting new members of educated people like college-age students, a number of terrorists who have been caught showing their status as students or college students. We consider one of the most important ways to be cultivated in a college environment by conducting radical anti-radical and anti-terrorist campaigns and campaigning the right way to deal with situations that focus on radical thinking and action and terrorism. This study will look at students' perceptions within the Faculty of Social and Political Sciences of the University of North Sumatra against the danger of radical understanding and understanding of terrorism and prevention solutions for the safety of their surrounding environment. The method used in this study is literature study, documentation and focus group discussion (FGD). The results of this study show a strong appreciation of student discussion groups on the intent and purpose of this activity.
\end{abstract}

Keywords: Utilization, Discussion Group, Student, Radicalism, Terrorism 
Humaizi. et al. Pendayagunaan Kelompok Diskusi Mahasiswa Dalam Menangkal Paham Radikalisme...

\section{PENDAHULUAN}

Provinsi Sumatera Utara sebagai salah satu daerah otonomi di Indonesia yang memiliki karakteristik demografi yang heterogen dimana populasi penduduk memiliki keberagaman dalam suku, agama dan etnisitas dan dipandang sebagai Provinsi yang kondusif hingga akhirnya beberapa waktu yang lalu tepatnya tahun pelaku terorisme mengambil daerah Provinsi Sumatera Utara sebagai daerah operasi meraka dengan melakukan perampokan Bank CIMB Niaga di Kota Medan.

Persoalan terorisme kini tengah merambah ke Indonesia, seperti kelompok teorisme Santoso yang masih di buru oleh kepolisian republic Indonesia. Pelaku teorisme secara perlahan masuk ke dunia perguruan tinggi dengan melakukan rekrutmen di kalangan mahasiswa seperti apa yang dikatakan oleh Sarwani salah seorang bekas anggota Negara Islam Indonesia (NII) melalui http://www.antaranews.com. $\quad$ Sarwani menjelaskan sejak tahun 2011 NII telah melakukan rekrutmen dari kalangan mahasiswa, menurut Sarwani fakta menunjukkan dari 19 aksi bom bunuh diri di Indonesia, pelakunya diketahui sebagai pelajar, mahasiswa dan pemuda yang berusia 19-30 tahun.

Fenomena rekrutmen di kalangan mahasiswa oleh pelaku teorisme terjawab dari serangkaian kegiatan penangkapan yang di lakukan kepolisian republik Indonesia (Polri) terhadap sejumlah mahasiswa yang di duga terlibat dengan jaringan terorisme seperti yang di lansir oleh media http://news.okezone.com yang menjelaskan Polri melakukan penangkapan terduga teroris di Desa Petulu, Kecamatan Ubud, Bali yang berstatus sebagai mahasiswa Jurusan Teknik Mesin di salah satu Universitas di Bandung. Bentuk keterlibatan kalangan mahasiswa dalam jaringan terorisme telah sampai pada perbuatan menyembunyikan pelaku terorisme seperti yang di lrilis oleh http://www.republika.co.id dengan judul berita "sembunyikan teroris, 3 mahasiswa di vonis 4 tahun penjara". Ketiga mahasiswa tersebut menyembunyikan pelaku terorisme, M.Syahrir dan Saefuddin Zuhri yang terkait kasus pengeboman hotel JW Marriot.
Fenomena teorisme yang merambah dunia perguruan tinggi tidak terkecuali pada daerah provinsi Sumatera Utara, fenomena terorisme dalam wilayah administrasi provinsi sumatera utara tercatat terjadi beberapa kali seperti perampokan Bank CIMB Niaga dan Polsek Hamparan Perak, Deli Serdang, Sumatera Utara (viva.co.id), terduga teroris jaringan sumatera utara tertangkap dan diantara terduga teroris merupakan kakak beradik http://www.tribunnews.com. Kemudian rangkaian kegiatan terorisme yang berada di lingkungan perguruan tinggi di Wilayah Provinsi Sumatera Utara terditeksi oleh aparat keamanan dengan modus pendekatan melalui cerama agama oleh terduga jaringan terorisme. Pemberitaan tribunnews.com menjelaskan pergerakan terorisme yang sering menggelar dakwah di Mesjid Al Munawarah UISU Medan melibatkan juga sejumlah mahasiswa setempat Direktur Kerja Sama Regional dan Multilateral Badan Nasional Penanggulangan Terorisme( BNPT), Herry Sudradjat, menyatakan, Sumut memang memiliki modal besar untuk mencegah terorisme, Sumut memiliki masyarakat yang multikultural dan toleransi yang sudah mengakar. Tapi di lain pihak, dengan berkembangnya teknologi informasi sangat mudah memperoleh informasi, sehingga paham radikal dari luar bisa lebih mudah masuk bagi kalangan anak muda dan orang-orang yang merasa terpinggirkan. Dalam pandangan Bandyopadhyay dan Sandle (2014: 112-123) rekrutmen teroris dibagi kepada dua golongan menurut keterampilannya yakni golongan tenaga terampil untuk bekerja di luar negeri dan tenaga kerja tidak terampil untuk dipekerjakan di dalam negeri. Kenyataan ini mendorong setiap negara untuk memperketat pengaturan kebijakan imigrasi.

Dari uraian yang beranjak melalui analisis fenomena dapat ditarik suatu kesimpulan bahwa di Wilayah Provinsi Sumatera Utara terdapat pelaku teorisme dan terdapat aktivitas penyebaran faham teorisme. Dari penelusuran studi literatur diperoleh begitu banyak kajian empiris yang mengangkat persoalan terorisme sepertiteori dari terorisme, namun teori terorisme yang di adopsi oleh Victoroff (2005: 4) dari Badey (1998) dan 
Humaizi. et al. Pendayagunaan Kelompok Diskusi Mahasiswa Dalam Menangkal Paham Radikalisme...

Laqueur (1999) dapat digunakan untuk mewakili teori yang ada berdasarkan konteks studi pada penulisan ini. (Badey 1998; Laqueur 1999) menjelaskan dua elemen yang umum dalam definisi terorisme (1) bahwa terorisme melibatkan agresi terhadap non kombatan dan (2) bahwa aksi teroris itu sendiri tidak diharapkan oleh pelaku untuk mencapai tujuan politik melainkan untuk mempengaruhi khalayak sasaran dan mengubah perilaku penonton di sini yang akan melayani kepentingan teroris .

Teori diatas dalam kaitannya dengan fenomena aksi teroris di Indonesia memiliki kemiripan dimana para pelaku teroris memilih tempat-tempat publik sebagai sasaran teror dan tujuan dari aksi teror di Indonesia lebih di refleksikan oleh publik sebagai ancaman keamanan di tempat umum ketimbang publik menganggap adanya tujuan-tujuan politik seperti keinginan mengubah ideologi negara atau sistem pemerintahan negara Indonesia. Studi empiris yang mengkaji tentang penyebaran faham terorisme melalui pendekatan agama di jelaskan oleh Wirsing (2004), Waseem (2004), Beek (2004), Das (2004), Jonjes (2004), Nair (2004), Kumar (2004), dan Rais (2004) dalam Limaye, Malik, and Wirsing (2004). Terhadap persoalan aksi terorisme yang muncul Victoroff (2005: 3 42) menerangkan adanya faktor-faktor sosial dan psikologis yang termodifikasi berkontribusi membentuk pola pikir teroris. Untuk menanggulangi teoris (Siqueira and Sandler 2006: 878-898) menawarkan kepemimpinan yang dapat meningkatkan kesejahteraan sekaligus mengurangi terorisme, karena menurut Razik, Ehring dan Emmelkamp (2013: 80-85) dampak serangan teroris sangat mengganggu kesehatan mental manusia yang menjadi korban langsung dan tidak langsung.

Dimensi kesejahteraan amat luas, namun setidaknya itu telah menjadi tugas negara dan masyarakat, dengan mengetahui persoalan terhadap kesejahteraan apa yang belum dicapai maka akan di ketahui pula model solusi yang tepat untuk dilakukan. Dalam konteks kelompok diskusi pada kalangan mahasiswa, tujuan utama dari aktivitas mereka ialah mencari kesejahteraan dalam bidang ilmu pengetahuan dalam tataran arts dan praxis. Terpenuhinya kesejahteraan dalam bidang ilmu pengetahuan dalam tataran arts dan praxis secara otomatis akan membekali mereka pada keterampilan yang dibutuhkan (softskill dan hardskill) untuk modal memenuhi kesejahteraan dalam bidang ekonomi pasca tamat kuliah di strata 1.

\section{METODE PENELITIAN}

Penelitian ini menggunakan metode kualitatif deskriptif. Data diperoleh melalui studi pustaka dan dokumentasi dan focus group discussion (FGD). Pihak yang terlibat dalam FGD berasal dari beberapa kalangan kelompok diskusi mahasiswa untuk mendapatkan kesimpulan persepsi mereka terhadap peran mereka dalam menangkal paham radikalisme dan paham terorisme di perguruan tingggi. Data diperoleh dari studi literatur, dokumentasi dan hasil FGD.

\section{HASIL DAN PEMBAHASAN}

Kegiatan pengabdian kepada masyarakat yang telah dilaksanakan ini dengan judul "Pendayagunaan Kelompok Diskusi Mahasiswa Dalam Menangkal Paham Radikalisme dan Paham Terorisme di Lingkungan Perguruan Tinggi" secara umum hasil pelaksanaan telah berjalan sebagaimana yang telah direncanakan. Adapun rangkaian kegiatan pengabdian kepada masyarakat ini di fokuskan kepada kelompok diskusi mahasiswa yang berada di lingkungan Universitas Sumatera Utara dan sekitarnya.

Kegiatan ini dilaksanakan dengan metode ceramah, diskusi dan tanya jawab yang dilakukan pada tanggal 25 Agustus 2017 pukul 10.00 WIB hingga pukul 12.00 WIB bertempat di FISIP USU dengan jumlah peserta berjumlah 107 Mahasiswa dari berbagai jurusan atau program studi yang ada di lingkungan Fakultas Ilmu Sosial dan Ilmu Politik. Kegiatan ini juga dilakukan kedua kalinya di sekitar lokasi yang sama dengan peserta yang berbeda yakni di lokasi Gedung Magister Studi Pembangunan dengan jumlah mahasiswa sebanyak 83 Mahasiswa yang berasal dari beragam program studi di lingkungan Universitas Sumatera Utara.

Secara umum dari kegiatan ini mendapatkan apresiasi yang kuat dari kalangan kelompok diskusi mahasiswa. Lebih detail 
Humaizi. et al. Pendayagunaan Kelompok Diskusi Mahasiswa Dalam Menangkal Paham Radikalisme...

apresiasi tersebut mengerucut pada satu kesimpulan bahwa peran kelompok diskusi mahasiswa diperlukan untuk menangkal paham radikalisme dan paham terorisme di lingkungan perguruan tinggi dengan cara memperhatikan konten materi dan pembahasan dari diskusi yang diikuti.

Dengan tingkat "kepekaan" yang tinggi terhadap lingkungan sekitar maka lingkungan akan terjaga dari segala bentuk bahaya yang dapat merusak pikiran. Sikap kordinatif senantiasa harus di jalin oleh kelompok diskusi mahasiswa kepada pihak aparat yang berwewenang agar penegakan hukum berjalan secara baik.

\section{PENUTUP}

\section{Kesimpulan}

Dari kegiatan yang dilaksanakan ini pada akhirnya memberikan kesimpulan bahwa peserta kegiatan pengabdian memperlihatkan kepedulian mereka terhadap bahaya yang ditimbulkan dari pengaruh paham radikal dan paham terorisme, pada sisi solusi dalam menangkal bahaya paham radikal dan paham terorisme para peserta sependapat untuk meningkatkan kepedulian yang tinggi terhadap perubahan lingkungan sekitar dan bilamana ada yang mencurigakan para peserta mengetahui cara terbaik ialah dengan melapor kepada pihak yang berwewenang dalam hal ini pemerintah desa, kepolisian sektor dan koramil. Akhir dari pada pandangan kolektif ini, para peserta akan mengkampanyekan nilai-nilai positif di lingkungan sekitar mereka.

\section{Saran}

Untuk dapat secara menerus melakukan upaya menangkal paham radikal dan paham terorisme di lingkungan perguruan tinggi maka kegiatan dalam bentuk kampanye menangkal paham radikal dan paham terorisme perlu dilakukan secara rutin di lingkungan perguruan tinggi atau setidak-tidaknya dalam kurun waktu setahun sekali. Dengan demikian setiap generasi baru (mahasiswa baru) akan mendapatkan "bekal" untuk menangkal diri dari pengaruh bahaya paham radikal dan terorisme.

\section{DAFTAR PUSTAKA}

Bandyopadhyay, S., Sandle, T, 2014. Immigration policy and counterterrorism. Journal of Public Economics, 110, pp. 112-123.

Limaye, S.P., Malik, M. \& Wirsing, R.G. eds., 2004. Religious Radicalism and Security in South Asia, Hawaii: Asia-Pacific Center For Security Studies.

Razik, Ehring dan Emmelkamp, 2013. Psychological consequences of terrorist attacks: Prevalence and predictors of mental health problems in Pakistani emergency responders. Psychiatry Research, 207, pp. 80-85.

Siqueira, K. \& Sandler, T., 2006. Terrorists versus the Government: Strategic Interaction, Support, and Sponsorship. Journal of Conflict Resolution, 50(6), pp.878-898.

Victoroff, J., 2005. The Mind of the Terrorist: A Review and Critique of Psychological Approaches. Journal of Conflict Resolution, 49(1), pp.3-42.

http://www.antaranews.com/berita/555275/peng akuan-bekas-anggota-nii-teroris-incar$\underline{\text { mahasiswa }}$

http://news.okezone.com/read/2016/02/16/337/1 313906/densus-tangkap-mahasiswaterduga-teroris-di-ubud.

http://www.republika.co.id/berita/pendidikan/ber ita/10/10/14/breakingnews/hukum/10/08/04/128095sembunyikan-teroris-3-mahasiswadivonis-4-tahun-penjara.

https://m.tempo.co/read/news/2016/04/25/05876 5753/ali-imron-teroris-bisa-ubah-polapikir-hanya-dalam-2-jam.

http://nasional.news.viva.co.id/news/read/17884 0-teroris-perampok-balas-dendam-di$\underline{\text { sumut- }}$ 
Humaizi. et al. Pendayagunaan Kelompok Diskusi Mahasiswa Dalam Menangkal Paham Radikalisme...

http://medan.tribunnews.com/2014/10/02/perger akan-teroris-di-mesjid-uisu-libatkanmahasiswa-gerakan-teroris-di-mesjiduisu-libatkan-mahasiswa. 